\title{
Novel seleno-hydantoin palladium(II) complex - antimigratory, cytotoxic and prooxidative potential on human colon HCT-116 and breast MDA-MB-231 cancer cells
}

\author{
Marko N. Živanovićn ${ }^{1}$, Jelena V. Košarić ${ }^{1}$, Biljana Šmit ${ }^{2}$, Dragana S. Šeklić ${ }^{1}$, Radoslav Z. \\ Pavlović ${ }^{2}$ and Snežana D. Marković ${ }^{1}$ \\ ${ }^{1}$ Department of Biology and Ecology, Faculty of Science, University of Kragujevac, Radoja Domanovića 12, 34000 Kragujevac, \\ Serbia \\ ${ }^{2}$ Department of Chemistry, Faculty of Science, University of Kragujevac, Radoja Domanovića 12, 34000 Kragujevac, Serbia
}

\begin{abstract}
Selenium and palladium containing compounds separately exert multifunctional effects on cells. While selenium containing compounds usually exert antioxidative properties, palladium(II) containing compounds are cytotoxic and prooxidative. Here we investigated biological effects of bicyclic seleno-hydantoin cis-7a-ethyl-5-methyl-5-phenylselanylmethyl-tetrahydro-pyrrolo[1,2-c] imidazole-1,3-dione (Hid-Se), and its palladium(II) complex, trans-bis-(cis-7a-ethyl-5-methyl5-phenylselanylmethyl-tetrahydro-pyrrolo[1,2-c]imidazole-1,3-dionato) palladium(II) chloride ((Hid-Se $\left.)_{2} \mathrm{Pd}\right)$ on human colon HCT-116 and breast MDA-MB-231 cancer cell lines. Hid-Se and (Hid-Se $)_{2} \mathrm{Pd}$ showed prooxidative and cytotoxic character. In all performed experiments (Hid-Se) ${ }_{2} \mathrm{Pd}$ proved to be more active, i.e. this substance exerted greater prooxidative effect, cytotoxicity and influence on cell migration potential. Even though Hid-Se and (Hid-Se) ${ }_{2} \mathrm{Pd}$ enhanced migration of HCT-116 cells, very important feature of these substances is the strong antimigratory potential on metastatic MDA-MB-231 cells.
\end{abstract}

Key words: Cancer - Cell Migration - Oxidative stress — Palladium - Selenium

\section{Introduction}

Cancer (malignant neoplasia) represents a large disease group, which is characterized by unregulated cell differentiation and formation of malignant tumors, which may invade other parts of the body affecting the basic physiological functions (Craig et al. 2010). In the field of cancer research the most of chemotherapeutic protocols are created with the aim of possessing the cytotoxic effects (Blagosklonny and Fojo 1999; Angelis et al. 2013). However, as primary tumors are significantly different from their metastatic analogues, the effect of a chemotherapeutic is not same on these types of tumors. Metastatic cells exhibit increased motility and increased cell migration from tumor stroma to other parts

Correspondence to: Marko N. Živanović, Department of Biology and Ecology, Faculty of Science, University of Kragujevac, Radoja Domanovića 12, 34000 Kragujevac, Serbia

E-mail: zivanovicm@kg.ac.rs of the body (Polyak and Weinberg 2009). Compared to traditional chemotherapy and radiotherapy methods, there are numerous studies which indicate anti-metastatic effects (Eckhardt et al. 2012; Deb et al. 2014).

Modern medicine is still largely focused on the application of platinum-containing (Kalinowska-Lis et al. 2008; Jevtic et al. 2014) and palladium-containing (Sabo et al. 2004; Matovic et al. 2013) chemotherapeutic cytotoxic agents. On the other hand, selenium has proven to be an important supplement for the suppression of the side effects of chemotherapy (Schroeder et al. 2004; Markovic et al. 2011; Brodin et al. 2015; Mut-Salud et al. 2016). Also, selenium-containing compounds exert inhibition of migration of cancer cells (Zec et al. 2012; Chen et al. 2013; Liu et al. 2015). Combining palladium and selenium in the same structure could provide a novel substance with benefits from the both elements. Substances, presented in this study combine bicyclic hydantoin structure and selenium in ligand, and additionally palladium(II) (Pd(II)) in complex of mentioned ligand. The 
goal of this study was to examine the cumulative effect of a hydantoin structure, selenium and palladium on cancer cells. Hydantoins are widely used compounds in cancer studies (Mudit et al. 2009; Hmuda et al. 2014). Moreover, bicyclic hydantoins are also studied (Ananda Kumar et al. 2009; Basappa et al. 2009). Although seleno-organic compounds (Kosaric et al. 2014; Bugarcic et al. 2015) and Pd(II) complexes of hydantoins are investigated (Kushev et al. 2002; Varbanov et al. 2010), according to our knowledge there are no records regarding antitumor activities of bicyclic selenohydantoins and their Pd(II) complexes.

In our investigations we used human adherent colorectal cancer cell line, HCT-116 and human mammary gland breast carcinoma metastatic cells, isolated from lung pleura, MDA-MB-231. Besides the tissue source difference of these two cell lines, one of their most significant differences is metastatic potential. While HCT-116 cells originate from primary tumor, MDA-MB-231 cells are of metastatic origin. Thus, in this study, in addition to investigation of effects of cytotoxicity and impact on redox status, we have chosen also to investigate the effects of tested substances on migratory potential of cells.

\section{Materials and Methods}

\section{Synthesis of Hid-Se and its Pd(II) complex (Hid-Se) ${ }_{2} \mathrm{Pd}$}

Synthesis of ligand, a seleno derivate of fused bicyclic hydantoin (cis-7a-ethyl-5-methyl-5-phenylselanylmethyltetrahydro-pyrrolo[1,2-c]imidazole-1,3-dione; Hid-Se), is shown in Scheme 1 and reported recently (Šmit and Pavlović 2015). In the reaction of the ligand with $\mathrm{PdCl}_{2}$, a complex with $\left.\left[\mathrm{PdCl}_{2} \text { (ligand }\right)_{2}\right]$ stoichiometry was obtained.

A solution of $17.7 \mathrm{mg}(0.1 \mathrm{mM}) \mathrm{PdCl}_{2}$ in acetonitrile $(15 \mathrm{ml})$ was heated under reflux for 2 hours. Yellow colored solution was cooled to room temperature and $70.3 \mathrm{mg}$ $(0.2 \mathrm{mM})$ of ligand (Hid-Se) dissolved in acetonitrile $(2.5 \mathrm{ml})$ was added dropwise. Reaction mixture was stirred during

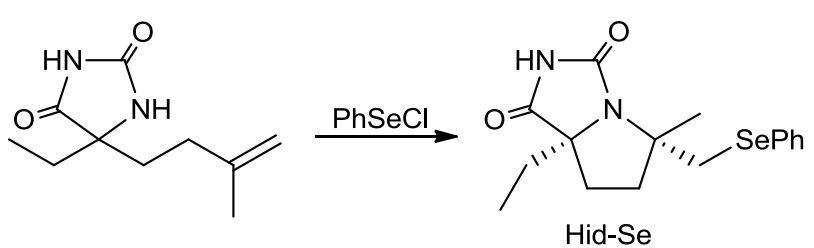

$2 \mathrm{Hid}-\mathrm{Se}+\mathrm{PdCl}_{2} \underset{\text { reflux, } 2 \mathrm{~h}}{\stackrel{\text { acetonitrile }}{\longrightarrow}}\left[\mathrm{PdCl}_{2}(\mathrm{Hid}-\mathrm{Se})_{2}\right]$

Scheme 1. Synthesis of Hid-Se and (Hid-Se) ${ }_{2} \mathrm{Pd}$
24 hours. Resulting yellow powder was filtered off and dried. Yield $60.9 \mathrm{mg}(69 \%)$.

The structure of the complex was confirmed on the basis of elemental analyses and spectral data.

IR (KBr) $v_{\text {max }}: 3419,3160,3055,2970,1767,1701,1576$, 1403, 1385, 1241, 1097, 922, 791, 740,687, $647 \mathrm{~cm}^{-1} \cdot{ }^{1} \mathrm{H}$ NMR $\left(200 \mathrm{MHz}\right.$, DMSO- $\left.d_{6}\right) \delta 0.78(\mathrm{t}, J=7.3 \mathrm{~Hz}, 3 \mathrm{H}), 1.41$ $(\mathrm{s}, 3 \mathrm{H}), 1.58-1.69(\mathrm{~m}, 1 \mathrm{H}), 1.73(\mathrm{q}, J=7.3 \mathrm{~Hz}, 2 \mathrm{H}), 1.97-2.13$ $(\mathrm{m}, 3 \mathrm{H}), 3.54(\mathrm{~d}, J=12.5 \mathrm{~Hz}, 1 \mathrm{H}), 3.75(\mathrm{~d}, J=12.5 \mathrm{~Hz}, 1 \mathrm{H})$, 7.20-7.41 (m, 3H), 7.47-7.65 (m, 2H), 10.77 (bs, $1 \mathrm{H}) .{ }^{13} \mathrm{C}$ (50 MHz, DMSO- $d_{6}$ ) $\delta 7.5,29.2,30.0,30.8,35.8,39.6,64.2$, $74.9,127.2,129.5,130.6,131.8,156.8,176.5$. Anal. calc. for $\mathrm{C}_{32} \mathrm{H}_{40} \mathrm{Cl}_{2} \mathrm{~N}_{4} \mathrm{O}_{4} \mathrm{PdSe}_{2} \mathrm{C}$ : 43.68, H: 4.58, N: 6.41\%; found C: 43.36, H: 4.40, N: $6.76 \%$.

\section{Chemicals}

Dulbecco's modified eagle medium (DMEM) and phosphate-buffered saline (PBS) were obtained from GIBCO, Invitrogen, USA. Foetal bovine serum (FBS) and trypsinEDTA were from PAA (The Cell Culture Company, Pasching, Austria). Dimethyl sulfoxide (DMSO), bovine serum albumin (BSA), 3-[4,5-dimethylthiazol-2-yl]-2,5-diphenyltetrazolium bromide (MTT), and nitro blue tetrazolium (NBT) were obtained from SERVA, Heidelberg, Germany. Polyvinyl alcohol mounting medium, N-1-napthylethylenediamine dihydrochloride were purchased from Fluka chemie GMBH, Buchs, Switzerland. Sulfanilamide and sulphosalicylic acid were purchased from MP Hemija Belgrade, Serbia. 5,5'-dithio-bis(2-nitrobenzoic acid) was purchased from Sigma Chemicals Co., St Louis, MO, USA. Paraformaldehyde originated from Merck, Germany. All solvents and chemicals were of analytical grade. The stock solutions were prepared in $100 \%$ DMSO at final concentration of $100 \mathrm{mM}$. Subsequent dilution was performed with DMEM cell growing medium, where in the highest treatment concentration $(500 \mu \mathrm{M})$ DMSO concentration was at $0.05 \%$, which is non-toxic to investigated cells.

\section{Cell preparation and cultivation}

Human colorectal HCT-116 and breast MDA-MB-231 cancer cell lines were purchased from the American Tissue Culture Collection (Manassas, VA, USA). The cells were cultivated in $75 \mathrm{~cm}^{2}$ culture flasks under controlled conditions in a humidified atmosphere with $5 \% \mathrm{CO}_{2}$ at $37^{\circ} \mathrm{C}$ in DMEM serum supplemented with $10 \%$ FBS and $100 \mathrm{IU} /$ $\mathrm{ml}$ penicillin and $100 \mu \mathrm{g} / \mathrm{ml}$ streptomycin until reaching a confluency of about $80 \%$. For MTT, NBT and Griess assays, $10^{4}$ cells were seeded in 96-well plates in triplicates for each treatment concentration, while for GSH assay it was seeded $5 \times 10^{4}$ cells per well. For immunofluorescence determination of expression of iNOS protein $7 \times 10^{4}$ cells 
were seeded in triplicates in 6-well plates on glass coverslips (Thermo Scientific), while for migratory potential inhibition assay $10^{5}$ cells per well were seeded in transwell cell culture chamber.

\section{Determination of cell viability and redox status parameters}

Cell viability was determined by MTT (Mosmann 1983) assay. Redox parameters: superoxide anion radical determined by NBT (Auclair and Voisin 1985), nitrites by Griess (Griess 1879) and glutathione by GSH assay (Baker et al. 1990). For investigation of influence of tested substances on cell viability and redox status we used standardized procedures briefly described in our previous papers (Kosaric et al. 2014; Petrovic et al. 2014, 2015). For the purposes of redox status assays we used concentrations of 1, 10, 50 and $100 \mu \mathrm{M}$, while $\mathrm{IC}_{50}$ values are determined as a plot of $\%$ cytotoxicity versus sample concentrations. All results were expressed as $\mu \mathrm{M}$.

\section{Inducible nitric oxide synthase (iNOS) protein expression (immunofluorescence microscopy)}

Inducible nitric oxide synthase (iNOS) protein expression in HCT-116 and MDA-MB-231 cells was detected by immunofluorescence method (Javois 1999). Cells were cultured in 6-well plates on glass coverslips. When cells were at about $80 \%$ confluence the supporting medium was removed and the cells were treated with medium containing tested substances at final concentration of 50 $\mu \mathrm{M}$. After $24 \mathrm{~h}$ medium was removed and cells were triple washed with PBS ( $\mathrm{pH} 7.2$ ). Next, the cells were fixed with $4 \% p$-formaldehyde in PBS for $20 \mathrm{~min}$ at $37^{\circ} \mathrm{C}$. After the fixation, the cells were washed three times with PBS and then permeabilized with methanol at $-20^{\circ} \mathrm{C}$ for $2 \mathrm{~min}$, washed with PBS three times and blocked on non-specific binding sites using 1\% BSA for $20 \mathrm{~min}$. The fixed cells were incubated with $20 \mu \mathrm{g} / \mathrm{ml}$ anti-iNOS specific primary antibody (RD Systems) for $1 \mathrm{~h}$ at $37^{\circ} \mathrm{C}$. Sample coverslips were then washed twice and incubated with anti-mouse secondary antibody conjugated with Alexa448 (Thermo Scientific) at a 1:200 dilution in PBS. DAPI was used to stain the cell nuclei (blue) at 1:1000 dilutions. Sample coverslips were washed twice and mounted on glass slide by polyvinyl alcohol mounting medium. The cell visualization was performed at Nikon inverted fluorescent microscope (Ti-Eclipse) at $600 \times$ magnification by using Nikon NISElements Advanced Research software.

\section{Migratory potential inhibition assay}

Principle of migratory assay is based on potential of investigated substance to inhibit or promote cell migration. Cells are placed on the upper layer of a cell permeable membrane with the medium containing tested substance. After incubation period, the cells which are migrated through the membrane were stained and counted. Migration of HCT116 and MDA-MB-231 cancer cells through $8 \mu \mathrm{m}$ filter pores was followed using Transwell cell culture chamber (ThinCert with translucent membranes, Greiner Bio-One $\mathrm{GmbH}$, Germany) (Entschladen et al. 2005). Firstly, cells that are cultured in DMEM medium with $10 \%$ FBS were twice washed with PBS and resuspended in the serum free DMEM medium. After centrifugation at $800 \mathrm{rpm}$ for 3 min the $10^{5}$ cells per well were resuspended in $500 \mu \mathrm{l}$ of serum free DMEM medium with addition of Hid-Se and (Hid-Se) ${ }_{2} \mathrm{Pd}$ and plated in 24-well plates onto the upper compartment of the chamber. The final concentrations of substances were 10 and $100 \mu \mathrm{M}$, respectively. In the lower compartment of the chamber $750 \mu$ of complete medium (DMEM with $10 \%$ FBS as chemoattractant) was added. The control cells have not been treated with the substances. After $24 \mathrm{~h}$ of incubation at $37^{\circ} \mathrm{C}$ and $5 \% \mathrm{CO}_{2}$ cells were washed three times with $\mathrm{PBS}$ and fixed with $4 \% p$-formaldehyde for 20 minutes at room temperature, followed by washing three times with PBS. After fixation, the cells were carefully and thoroughly removed with cotton swab. Remains of cells at the lower part of the Transwell membrane were stained with $0.1 \%$ of Crystal Violet in 200 mM MES buffer, pH 6.0 for 10 minutes at room temperature. After washing, and drying at room temperature overnight, membranes were cut and placed in another 24-well plate. Crystal Violet stained membranes were resuspended in $100 \mu \mathrm{l} 10 \%$ acetic acid and $80 \mu \mathrm{l}$ of stained acetic acid solution was moved to a 96-well microtiter plate with subsequent reading of optical density at $595 \mathrm{~nm}$ at Microplate reader.

\section{Statistics}

All experimental data were expressed as mean \pm standard error (SE). Biological activity assays are performed in triplicate for each dose. Statistical significance was determined using the one-way ANOVA test for multiple comparisons. $p<0.05$ was considered as significant. The magnitude of correlation between variables was done using SPSS (Chicago, IL) statistical software package (SPSS for Windows, version $17,2008)$. The $I_{50}$ values were calculated from the dose curves by a computer program (CalcuSyn).

\section{Results}

\section{Cytotoxic effects}

The cytotoxicity of investigated substances was determined by MTT assay. The results were expressed graphically in 
Table 1. Growth inhibitory effects - $\mathrm{IC}_{50}$ values of Hid-Se and (Hid-Se) ${ }_{2}$ Pd on HCT-116 and MDA-MB-231 cell lines after 24 and $72 \mathrm{~h}$ of exposure

\begin{tabular}{lccccc}
\hline \multirow{2}{*}{$\begin{array}{l}\text { Tested } \\
\text { substance }\end{array}$} & \multicolumn{4}{c}{$\mathrm{IC}_{50}(\mu \mathrm{M})$} \\
\cline { 2 - 3 } \cline { 5 - 6 } & \multicolumn{2}{c}{ HCT-116 } & & \multicolumn{2}{c}{ MDA-MB-231 } \\
\cline { 2 - 3 } \cline { 5 - 6 } Hid-Se & $>500$ & $92.1 \pm 3.1$ & & $>500$ & $288.5 \pm 13.8$ \\
(Hid-Se) ${ }_{2} \mathrm{Pd}$ & $105.7 \pm 8.4$ & $130.7 \pm 7.6$ & & $>500$ & $81.6 \pm 7.2$ \\
\hline
\end{tabular}

All values are mean \pm SE.

Figure 1 and as $\mathrm{IC}_{50}$ values presented in Table 1. Evaluation on HCT-116 cells revealed that investigated substances exhibit cytotoxic character. Hid-Se induced decreasing of cell viability in dose and time depended manner, with significant toxicity $72 \mathrm{~h}$ from treatment. On the other hand, (Hid-Se) ${ }_{2} \mathrm{Pd}$ exhibits more significant cytotoxic effect acutely, i.e. after $24 \mathrm{~h}$. Based on the obtained results, (Hid-Se) ${ }_{2} \mathrm{Pd}$ is more cytotoxic to HCT-116 cells than Hid-Se. On MDA-MB-231 cells, investigated substances showed cytotoxic character exhibited in dose and time dependent manner, i.e. with in- creasing the substance concentration cell viability decreased which is more evident $72 \mathrm{~h}$ from treatment. After $24 \mathrm{~h}$ from treatment the both substances exhibited no cytotoxic effect, while after $72 \mathrm{~h}$ the cytotoxic effect was obvious. The more significant effect was obtained with (Hid-Se) ${ }_{2} \mathrm{Pd}$. From the results explaining cytotoxic character one could observe that HCT-116 cells are more sensitive to the investigated substances than MDA-MB-231 cells.

\section{Redox status}

\section{Superoxide anion radical $\left(\mathrm{O}_{2}^{\cdot-}\right)$ concentration}

Superoxide anion radical, $\mathrm{O}_{2}{ }^{--}$is an important indicator of reactive oxygen species (ROS) level (Hancock et al. 2001). $\mathrm{O}_{2}{ }^{\cdot-}$ was determined by spectrophotometric NBT assay, and results of measurement are depicted in Table 2. Measurement on HCT-116 cells revealed that Hid-Se and (Hid-Se) ${ }_{2} \mathrm{Pd}$ induced significant change in $\mathrm{O}_{2}{ }^{--}$content.

After $24 \mathrm{~h} \mathrm{Hid-Se}$ induced decreasing of $\mathrm{O}_{2}{ }^{--}$in low concentrations, while higher concentrations significantly increased $\mathrm{O}_{2}{ }^{--}$. On the other hand, $72 \mathrm{~h}$ from treatment Hid-Se decreased $\mathrm{O}_{2}{ }^{--}$content. Similar decreasing was

\section{HCT-116}
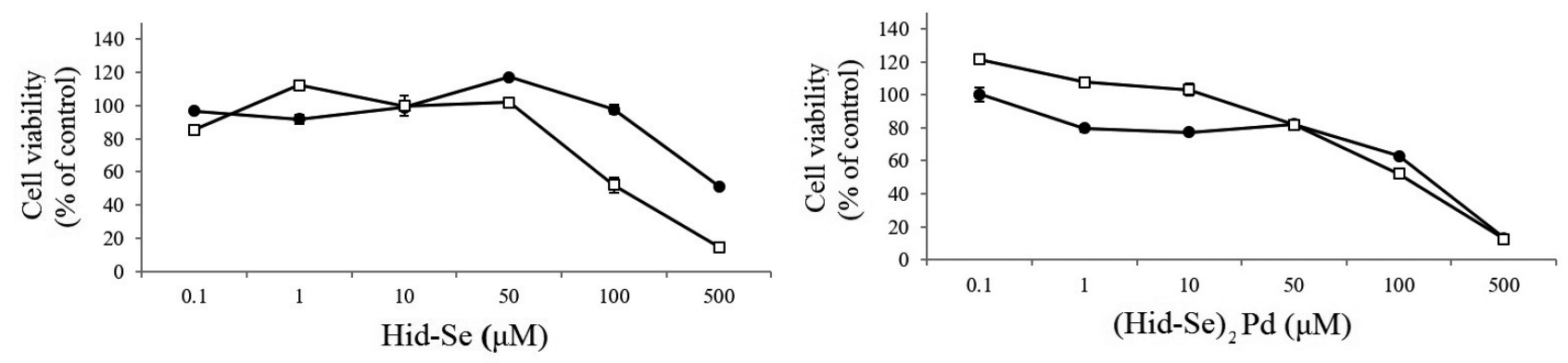

MDA-MB-231
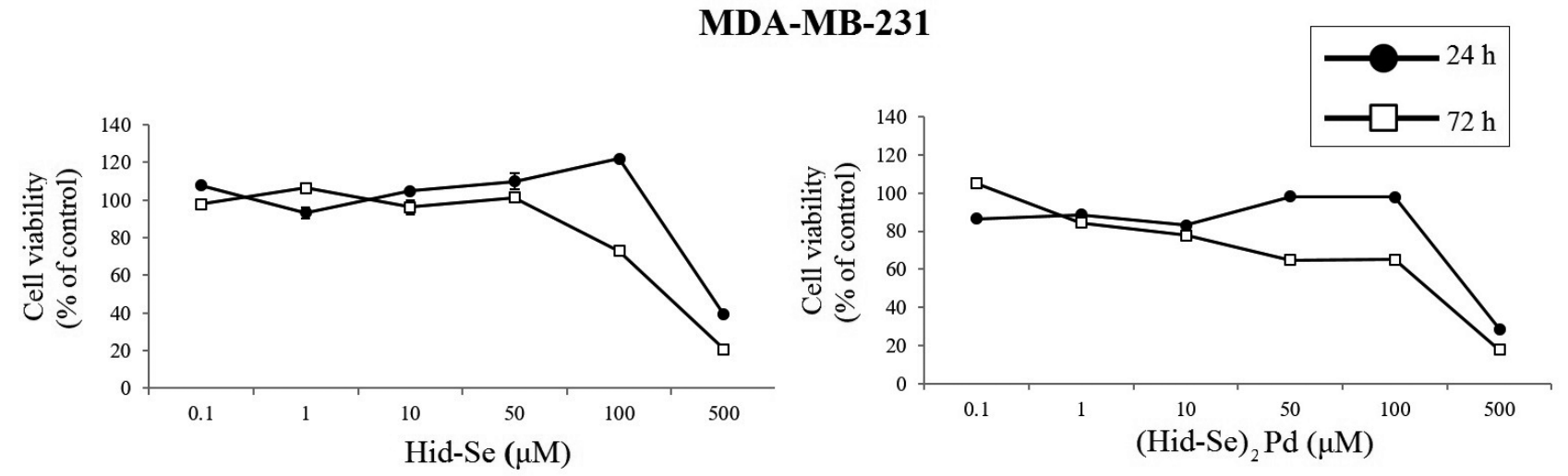

Figure 1. The dose response curve of effect of Hid-Se and (Hid-Se) ${ }_{2} \mathrm{Pd}$ on HCT-116 and MDA-MB-231 cell lines after 24 and $72 \mathrm{~h}$ of exposure. All values are mean \pm SE. 
Table 2. Effects of Hid-Se and (Hid-Se) ${ }_{2} \mathrm{Pd}$ on HCT-116 and MDA-MB-231 cell lines, expressed as the $\mathrm{O}_{2}{ }^{{ }^{--}}$concentration after $24 \mathrm{~h}$ and $72 \mathrm{~h}$ of exposure

\begin{tabular}{|c|c|c|c|c|c|c|c|c|}
\hline \multirow{4}{*}{$\begin{array}{l}\text { Concentration } \\
(\mu \mathrm{M})\end{array}$} & \multicolumn{8}{|c|}{ Superoxide anion radical, $\mathrm{O}_{2}{ }^{--}(\mu \mathrm{M})$} \\
\hline & \multicolumn{4}{|c|}{ HCT-116 } & \multicolumn{4}{|c|}{ MDA-MB-231 } \\
\hline & \multicolumn{2}{|c|}{ Hid-Se } & \multicolumn{2}{|c|}{$(\text { Hid-Se })_{2} \mathrm{Pd}$} & \multicolumn{2}{|c|}{ Hid-Se } & \multicolumn{2}{|c|}{$(\mathrm{Hid}-\mathrm{Se})_{2} \mathrm{Pd}$} \\
\hline & $24 \mathrm{~h}$ & $72 \mathrm{~h}$ & $24 \mathrm{~h}$ & $72 \mathrm{~h}$ & $24 \mathrm{~h}$ & $72 \mathrm{~h}$ & $24 \mathrm{~h}$ & $72 \mathrm{~h}$ \\
\hline 0 & $39.20 \pm 0.20$ & $29.04 \pm 0.54$ & $39.20 \pm 0.20$ & $29.04 \pm 0.54$ & $25.12 \pm 0.12$ & $24.88 \pm 0.38$ & $25.12 \pm 0.12$ & $24.88 \pm 0.38$ \\
\hline 1 & $35.28 \pm 1.78^{*}$ & $28.76 \pm 0.14$ & $33.93 \pm 1.58^{*}$ & $25.23 \pm 0.23^{*}$ & $27.91 \pm 0.06^{*}$ & $26.04 \pm 0.30^{*}$ & $30.68 \pm 2.22^{*}$ & $25.40 \pm 0.43$ \\
\hline 10 & $31.91 \pm 0.17^{\star}$ & $29.57 \pm 0.38$ & $33.75 \pm 2.00^{\star}$ & $26.08 \pm 0.27^{\star}$ & $27.05 \pm 0.17^{\star}$ & $24.03 \pm 1.09$ & $27.69 \pm 0.30^{\star}$ & $29.11 \pm 1.35^{\star}$ \\
\hline 50 & $38.88 \pm 0.66$ & $26.53 \pm 0.10^{\star}$ & $31.65 \pm 1.71^{\star}$ & $25.40 \pm 0.05^{*}$ & $28.32 \pm 1.70^{\star}$ & $22.37 \pm 0.10^{\star}$ & $27.75 \pm 0.21^{\star}$ & $30.00 \pm 1.35^{\star}$ \\
\hline 100 & $44.29 \pm 1.59^{*}$ & $25.40 \pm 1.05^{*}$ & $36.57 \pm 0.49$ & $30.52 \pm 1.81$ & $28.28 \pm 1.59^{\star}$ & $26.08 \pm 1.42$ & $26.75 \pm 0.34^{\star}$ & $36.31 \pm 1.59^{*}$ \\
\hline
\end{tabular}

${ }^{*} p<0.05$ as compared to the control cells.

observed with (Hid-Se) ${ }_{2} \mathrm{Pd}$ in both treatment periods. (Hid-Se) ${ }_{2} \mathrm{Pd}$ exerted stronger reduction of $\mathrm{O}_{2}{ }^{--}$content than Hid-Se on HCT-116 cells. While tested substances, in general, decreased $\mathrm{O}_{2}{ }^{--}$in HCT-116 cells, on MDA-MB-231 cells they acted as prooxidants, i.e. induced significant increasing in $\mathrm{O}_{2}{ }^{--}$content 24 and $72 \mathrm{~h}$ from treatment. This effect was stronger after $24 \mathrm{~h}$, where (Hid-Se) ${ }_{2} \mathrm{Pd}$ again showed greater influence. Comparison of these two cell lines showed that $\mathrm{O}_{2}{ }^{--}$production was greater on MDAMB-231 cells.

\section{Nitrites $\left(\mathrm{NO}_{2}^{-}\right)$concentration}

Concentration of nitrites indicates quantity of nitrosonium ions $\left(\mathrm{NO}^{+}\right)$in anaerobic conditions. In water, the final product of aerobic phase reaction between nitrogen oxide $(\mathrm{NO})$ and $\mathrm{O}_{2}$ is nitrogen dioxide $\left(\mathrm{NO}_{2}\right)$, which quickly combines with excess of NO, forming nitrogen trioxide $\left(\mathrm{N}_{2} \mathrm{O}_{3}\right)$ that is hydrolyzed to nitrites. So, nitrite concentration may indicate level of $\mathrm{NO}$ and other reactive nitrogen species (RNS) in cells (Lancaster 2006). Results of measurement of nitrite level are presented in Table 3. On HCT-116 cells in treatment with Hid-Se it was observed decreasing of nitrites, except in the highest concentration which induced significant increasing. (Hid-Se) ${ }_{2} \mathrm{Pd}$ significantly induced increasing of nitrites. On MDA-MB-231 cells after $24 \mathrm{~h}$ Hid-Se in lower concentrations induced decreasing, while higher concentrations induced increasing of nitrite concentration. After $72 \mathrm{~h}$ change of nitrites was not significant as after $24 \mathrm{~h}$. (Hid-Se) ${ }_{2} \mathrm{Pd}$ predominantly induced significant increasing of nitrite level. Similarly to NBT test, measurement of nitrite concentration indicated MDA-MB-231 cells as more sensitive to investigated substances when compared to HCT-116 cells.

\section{Reduced glutathione (GSH) concentration}

Glutathione is an important tripeptide responsible for neutralizing of ROS/RNS and thus for maintaining the redox equilibrium in eukaryotic cell (Pompella et al. 2003). Table 4 represents the effects of investigated substances on GSH level in HCT-116 and MDA-MB-231 cells. On HCT-116 we

Table 3. Effects of Hid-Se and (Hid-Se) ${ }_{2} \mathrm{Pd}$ on HCT-116 and MDA-MB-231 cell lines, expressed as the $\mathrm{NO}_{2}{ }^{-}$concentration after $24 \mathrm{~h}$ and $72 \mathrm{~h}$ of exposure

\begin{tabular}{|c|c|c|c|c|c|c|c|c|}
\hline \multirow{4}{*}{$\begin{array}{l}\text { Concentration } \\
(\mu \mathrm{M})\end{array}$} & \multicolumn{8}{|c|}{ Nitrites, $\mathrm{NO}_{2}^{-}(\mu \mathrm{M})$} \\
\hline & \multicolumn{4}{|c|}{ НCT-116 } & \multicolumn{4}{|c|}{ MDA-MB-231 } \\
\hline & \multicolumn{2}{|c|}{ Hid-Se } & \multicolumn{2}{|c|}{$(\mathrm{Hid}-\mathrm{Se}){ }_{2} \mathrm{Pd}$} & \multicolumn{2}{|c|}{ Hid-Se } & \multicolumn{2}{|c|}{$(\mathrm{Hid}-\mathrm{Se})_{2} \mathrm{Pd}$} \\
\hline & $24 \mathrm{~h}$ & $72 \mathrm{~h}$ & $24 \mathrm{~h}$ & $72 \mathrm{~h}$ & $24 \mathrm{~h}$ & $72 \mathrm{~h}$ & $24 \mathrm{~h}$ & $72 \mathrm{~h}$ \\
\hline 0 & $33.85 \pm 0.15$ & $45.77 \pm 0.77$ & $33.85 \pm 0.15$ & $45.77 \pm 0.77$ & $43.65 \pm 0.65$ & $50.77 \pm 0.47$ & $43.65 \pm 0.65$ & $50.77 \pm 0.47$ \\
\hline 1 & $18.28 \pm 0.25^{\star}$ & $55.77 \pm 2.78^{\star}$ & $41.81 \pm 2.60^{*}$ & $47.80 \pm 3.25$ & $29.08 \pm 1.73^{\star}$ & $55.31 \pm 1.12^{*}$ & $42.50 \pm 2.43$ & $58.55 \pm 0.53^{*}$ \\
\hline 10 & $24.35 \pm 0.89^{\star}$ & $51.60 \pm 2.99^{*}$ & $45.49 \pm 2.75^{\star}$ & $44.35 \pm 0.79$ & $36.03 \pm 1.48^{\star}$ & $50.13 \pm 2.62$ & $65.78 \pm 9.00^{*}$ & $53.02 \pm 0.12^{*}$ \\
\hline 50 & $23.96 \pm 1.03^{*}$ & $54.32 \pm 0.40^{*}$ & $53.67 \pm 0.20^{*}$ & $51.25 \pm 0.68^{\star}$ & $78.65 \pm 8.25^{\star}$ & $48.64 \pm 0.17$ & $91.23 \pm 5.93^{*}$ & $48.17 \pm 2.63$ \\
\hline 100 & $60.12 \pm 1.26^{*}$ & $32.95 \pm 4.94^{*}$ & $57.58 \pm 0.69^{*}$ & $45.78 \pm 3.46$ & $66.38 \pm 9.50^{*}$ & $48.45 \pm 2.59$ & $84.20 \pm 2.83^{*}$ & $52.95 \pm 0.53$ \\
\hline
\end{tabular}

${ }^{*} p<0.05$ as compared to the control cells. 
Table 4. Effects of Hid-Se and (Hid-Se) ${ }_{2} \mathrm{Pd}$ on HCT-116 and MDA-MB-231 cell lines, expressed as the GSH concentration after $24 \mathrm{~h}$ and $72 \mathrm{~h}$ of exposure

\begin{tabular}{|c|c|c|c|c|c|c|c|c|}
\hline \multirow{4}{*}{$\begin{array}{l}\text { Concentration } \\
(\mu \mathrm{M})\end{array}$} & \multicolumn{8}{|c|}{ GSH $(\mu \mathrm{M})$} \\
\hline & \multicolumn{4}{|c|}{ HCT-116 } & \multicolumn{4}{|c|}{ MDA-MB-231 } \\
\hline & \multicolumn{2}{|c|}{ Hid-Se } & \multicolumn{2}{|c|}{$($ Hid-Se $){ }_{2} \mathrm{Pd}$} & \multicolumn{2}{|c|}{ Hid-Se } & \multicolumn{2}{|c|}{$(\mathrm{Hid}-\mathrm{Se})_{2} \mathrm{Pd}$} \\
\hline & $24 \mathrm{~h}$ & $72 \mathrm{~h}$ & $24 \mathrm{~h}$ & $72 \mathrm{~h}$ & $24 \mathrm{~h}$ & $72 \mathrm{~h}$ & $24 \mathrm{~h}$ & $72 \mathrm{~h}$ \\
\hline 0 & $19.04 \pm 0.14$ & $15.61 \pm 0.11$ & $19.04 \pm 0.14$ & $15.61 \pm 0.11$ & $16.94 \pm 0.44$ & $19.55 \pm 0.45$ & $16.94 \pm 0.44$ & $19.55 \pm 0.45$ \\
\hline 1 & $18.35 \pm 0.49$ & $14.52 \pm 0.34$ & $18.60 \pm 0.32$ & $15.23 \pm 0.53$ & $18.56 \pm 1.51$ & $27.51 \pm 1.51^{\star}$ & $18.63 \pm 0.26^{*}$ & $16.88 \pm 0.30$ \\
\hline 10 & $18.30 \pm 0.21$ & $14.06 \pm 0.24$ & $21.77 \pm 0.21^{\star}$ & $16.91 \pm 0.15^{\star}$ & $19.54 \pm 1.36$ & $23.45 \pm 0.97^{\star}$ & $21.61 \pm 0.98^{\star}$ & $25.03 \pm 2.05^{\star}$ \\
\hline 50 & $18.09 \pm 0.21$ & $16.07 \pm 0.30$ & $20.75 \pm 0.93$ & $16.32 \pm 0.38$ & $20.14 \pm 0.22^{\star}$ & $23.28 \pm 2.50^{*}$ & $16.95 \pm 0.15$ & $20.69 \pm 0.88$ \\
\hline 100 & $19.97 \pm 0.29$ & $16.56 \pm 0.73$ & $18.45 \pm 0.74$ & $16.52 \pm 0.19$ & $20.14 \pm 1.58^{*}$ & $22.73 \pm 1.19^{*}$ & $17.09 \pm 0.34$ & $18.78 \pm 0.94$ \\
\hline
\end{tabular}

${ }^{*} p<0.05$ as compared to the control cells. GSH, reduced glutathione.

observed a moderate effect on GSH level change, i.e. HidSe did not induced any statistically significant changing of GSH concentration, while cells treated with (Hid-Se) ${ }_{2} \mathrm{Pd}$ slightly increased GSH level. This increasing was slightly higher after $24 \mathrm{~h}$. On MDA-MB-231 cells it was observed significant increasing in GSH level with both substances. It could be concluded that greater increasing in GSH for (Hid-Se) ${ }_{2} \mathrm{Pd}$ is followed by greater increasing in ROS/RNS induced with this substance. Thus, cells respond to changing in redox equilibrium by lesser or greater induction in GSH production.

\section{Inducible nitric oxide synthase (iNOS) protein expression}

Nitric oxide synthase is a protein which induces the synthesis of NO from L-arginine (Liu and Gross 1996). In order to investigate the possible origin of the increase of nitrites we considered examination of the expression of iNOS protein. On HCT-116 cells $24 \mathrm{~h}$ from treatment Hid-Se in concentration of $50 \mu \mathrm{M}$ decreased expression of iNOS protein (Figure 2). Similarly, in the same measuring conditions Hid-Se significantly decreased nitrite content (Table 3 ). On the other hand, (Hid-Se) ${ }_{2} \mathrm{Pd}$ significantly increased
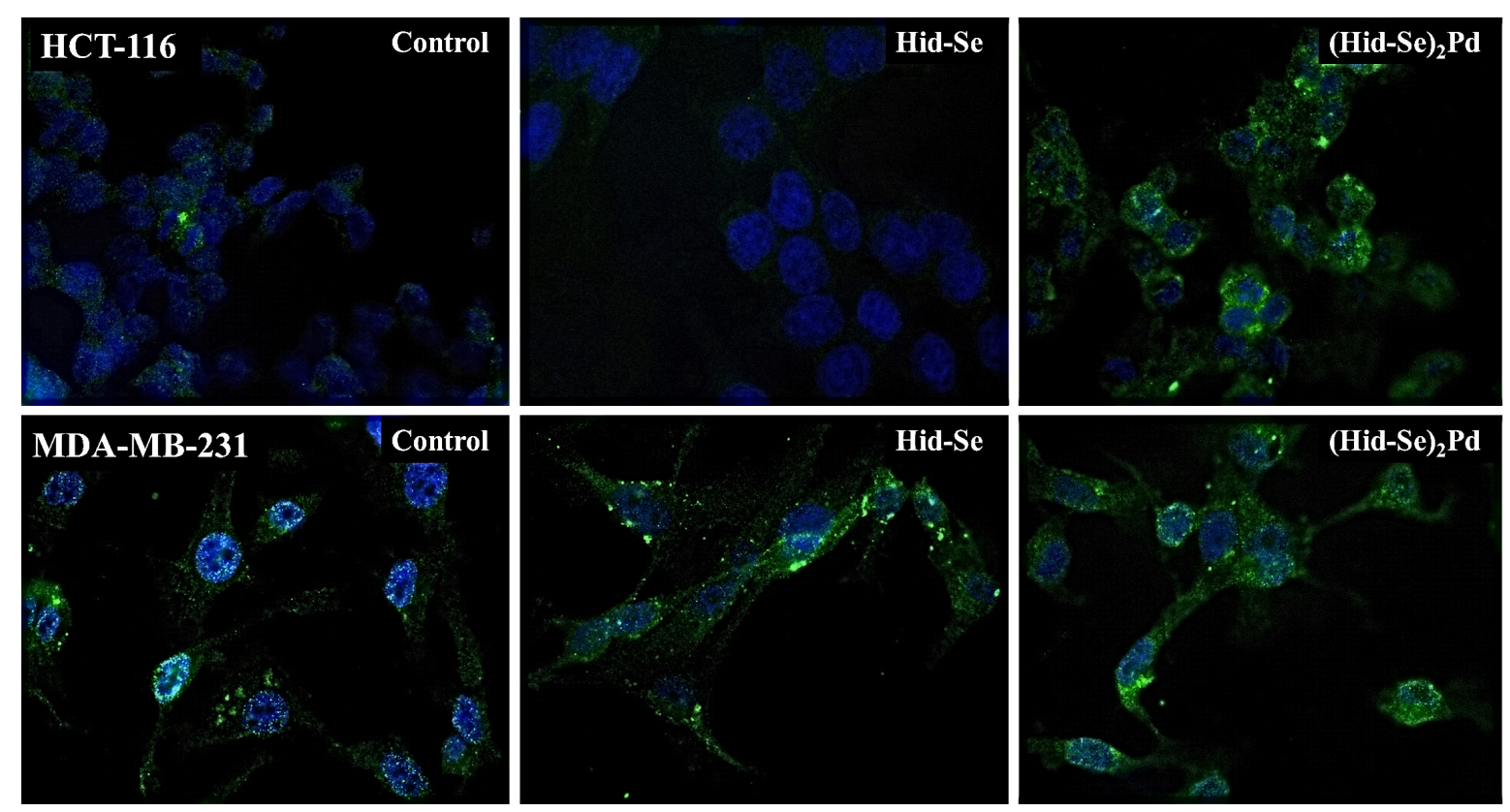

Figure 2. Detection of iNOS protein expression in HCT-116 and MDA-MB-231 cells by immunofluorescence staining. Cells are treated with $50 \mu \mathrm{M}$ substances and iNOS protein expression was examined $24 \mathrm{~h}$ from treatment. Cell nuclei are DAPI stained to blue, while iNOS proteins are green (NIS-Elements Advanced Research Captures merged). All sections were examined by Nikon inverted fluorescent microscope (Ti-eclipse) at $600 \times$ magnification. 
iNOS protein expression, which also could be related to the nitrite production (Table 3 ). On MDA-MB-231 cells both substances induced significant increasing of iNOS protein expression.

\section{Migratory potential inhibition}

To evaluate influence of tested substances on migratory potential we examined the migration of cells through Transwell membrane assembled in 24 -well plate. The size of pores on Transwell membrane is $8.0 \mu \mathrm{m}$, i.e. small enough compared to cancer cells. Thus, investigated cells influenced by substances, could only actively migrate through the pores in greater or smaller extent. Influence of tested substances on migratory potential of HCT-116 cells is less significant when compared to the results obtained with MDA-MB-231 cells (Figure 3). Investigated substances induced increasing of HCT-116 motility. Hid-Se in concentration of $10 \mu \mathrm{M}$ showed no effect, while concentration of $100 \mu \mathrm{M}$ increased migration for about $15 \%$. On the other hand (Hid-Se) ${ }_{2} \mathrm{Pd}$ increased cell migration in concentrations of $10 \mu \mathrm{M}$ and $100 \mu \mathrm{M}$ for 60 and $80 \%$, respectively. MDA-MB-231 cells are influenced in a great extent, especially in concentration of $100 \mu \mathrm{M}$. Hid-Se induced no statistically significant change in concentration of $10 \mu \mathrm{M}$, but $100 \mu \mathrm{M}$ reduced migration for about $65 \%$. (Hid-Se) ${ }_{2} \mathrm{Pd}$ in concentration of $10 \mu \mathrm{M}$ increased migration for $20 \%$, while $100 \mu \mathrm{M}$ reduced migration for $60 \%$. All results presented in Figure 3 are recalculated in relation with the number of survived cells estimated in MTT assay.

\section{Discussion}

Results presented in this paper are the first investigation of biological activity of such fused bicyclic seleno-hydantoin and its Pd(II) complex on cancer cell lines. Cytotoxic character of Pd(II) complexes, hydantoins and seleno-derivatives is proved and well explained in numerous articles (Kushev et al. 2002; Sabo et al. 2004; Ananda Kumar et al. 2009; Basappa et al. 2009; Mudit et al. 2009; Varbanov et al. 2010; Matovic et al. 2013; Hmuda et al. 2014; Kosaric et al. 2014; Bugarcic et al. 2015). Comparing with results obtained in this article, many of tested $\mathrm{Pd}$ (II) complexes, seleno-organic compounds, hydantoins and their combinations exerted considerable cytotoxicity on cancer cell lines. Such pronounced cytotoxicity in most cases is closely related to their prooxidative character. This point of view is important, but one of the most important features that also could be followed is the influence on potential of cancer cells to migrate. Our results suggest that these compounds possess potential to reduce migration of metastatic MDA-MB-231 cells.

At the beginning it was considered that $\mathrm{Pd}(\mathrm{II})$ complexes possess no anti-tumor properties. Compared to cisplatin, cispalladium, cis- $\left[\mathrm{Pd}\left(\mathrm{NH}_{3}\right)_{2} \mathrm{Cl}_{2}\right]$ complex does not show anti-tumor activity. Coordination chemistry of $\mathrm{Pd}(\mathrm{II})$ and $\mathrm{Pt}(\mathrm{II})$ is very similar whereas their structural and equilibrium behavior of the solutions are very similar (Bugarčić et al. 2015), but introduction of specific ligands in coordination with Pd(II) can result with great anti-tumor activities (Divsalar et al. 2011; Ulukaya et al. 2011). Compared to action of the cisplatin presented in our previous article (Petrovic et al. 2015), our results showed that Hid-Se exerts lower cytotoxic effects, while (Hid-Se) ${ }_{2} \mathrm{Pd}$ showed greater effect $24 \mathrm{~h}$ after treatment on HCT-116 cells and lower but comparable effect on MDA-MB-231 cells. From the presented results it could be concluded that Hid-Se and especially (Hid-Se) ${ }_{2} \mathrm{Pd}$ exert cytotoxic character. More significant effect showed (HidSe) ${ }_{2} \mathrm{Pd}$, especially on HCT-116 cells. Cytotoxicity is closely related to enhanced production of ROS/RNS, i.e. superoxide anion radical and nitrites. The produced $\mathrm{O}_{2}{ }^{--}$could be from many possible origins. One is that structures of investigated
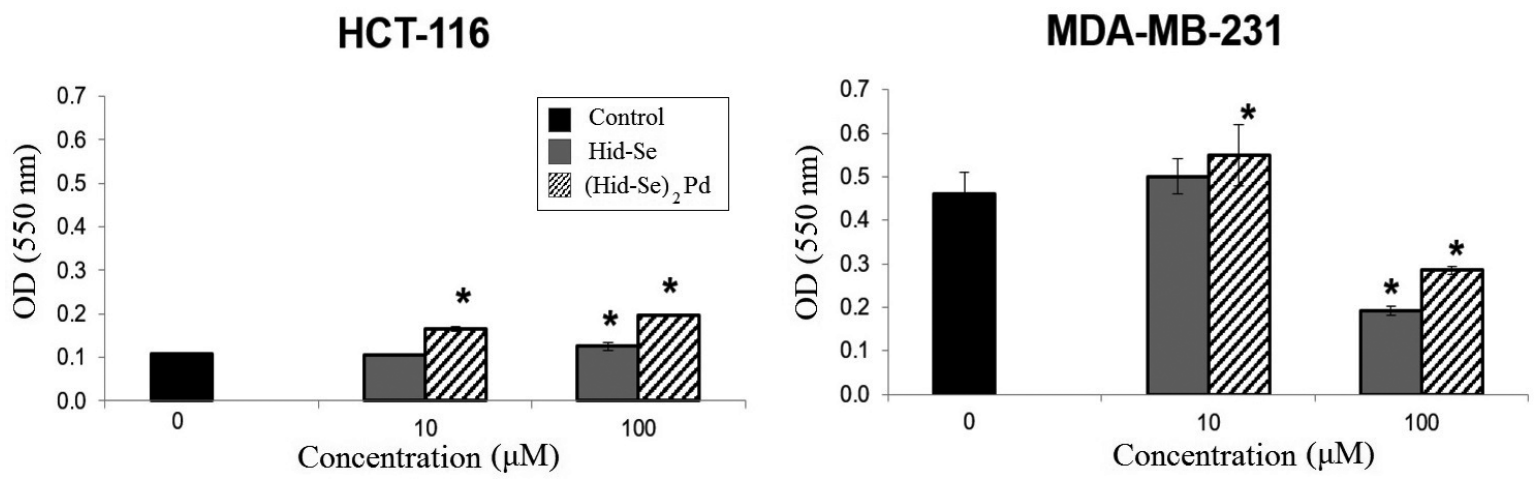

Figure 3. The influence of Hid-Se and (Hid-Se) ${ }_{2} \mathrm{Pd}$ on migratory potential of HCT-116 and MDA-MB-231 cells, after $24 \mathrm{~h}$ of treatment related to the number of viable cells. The cells were treated with substances with concentrations of 10 and $100 \mu \mathrm{M}$. All values are mean $\pm \mathrm{SE}, n=2,{ }^{*} p<0.05$ as compared to control. OD, optical density measured spectrophotometrically on $595 \mathrm{~nm}$. 
substances possess asymmetric electron densities that could provide electron(s) that could subsequently start radical chain reaction. Another source certainly could be explained by Fenton reaction inside the cells. $\mathrm{H}_{2} \mathrm{O}_{2}$ created in cells easily reacts with iron yielding $\mathrm{O}_{2}{ }^{--}$. Besides iron, also many transition metals could catalyze Fenton reaction, such as palladium, platinum and rhodium (Halliwell and Gutteridge 2007). Nitrites, and thus the NO in cancer cell, also could be originated from a wide range of sources. One of possibilities, we intended to investigate was iNOS. This specific protein from the family of nitric oxide synthases (NOS) could be responsible for statistically significant formation of nitrites and also according to Xu et al. (2002) for the cytotoxicity in tumor cells. Our results follow strong relationship between iNOS synthesis induction/suppression and nitrite level in tested cells. According to showed analogy, we could suggest that these substances significantly influenced iNOS protein expression, and thus the increasing or decreasing of level of nitrites. On the other hand, NO (and thus nitrite) level greatly depends on $\mathrm{O}_{2}{ }^{--}$production. This could be explained by fact that $\mathrm{O}_{2}{ }^{--}$possess great affinity towards $\mathrm{NO}$, forming peroxynitrites (Ferrer-Sueta and Radi 2009). Also, the fact that investigated substances contain a lot of nitrogen atoms in their imidazole structure could offer a possibility that substances were metabolized by cells. As the human cell is very complex system, every source that impacts at least one of the intracellular parameters greatly influences the redox equilibria (Cordero and deMiguel 2012). Greater production of free radical species influenced greater production of glutathione, which is in agreement with the nature of GSH and its cellular defense role against disruption of redox equilibria. Hid-Se does not possess such a denominated prooxidative and cytotoxic character as (Hid-Se) ${ }_{2} \mathrm{Pd}$ does, thus the changing in GSH level influenced by Hid-Se is not as significant as with (Hid-Se) ${ }_{2} \mathrm{Pd}$.

In addition to examination of the influence of tested substances on the viability and redox status of cells, testing the impact on migratory potential is also very important. A certain substance does not need to possess significant cytotoxic character, but if given substance significantly reduces the migratory potential then it may be considered as potentially interesting for further studies towards the synthesis the appropriate drug. Our results showed that Hid-Se and (Hid-Se) ${ }_{2} \mathrm{Pd}$ induced increasing in migration potential of HCT-116 cells. On the other hand, these substances greatly decreased the migration potential of metastatic MDA-MB-231 breast cancer cells. The occurrence that MDA-MB-231 cells migrate more intensive than HCT-116 cells is previously described (Wu et al. 2011), and the result indicating that MDA-MB-231 cells are migratory limited is promising. Also, it has been found that significant increase in ROS/RNS has direct impact on antimigratory effect on cancer cells (Urbich et al. 2002). It was found that moderate production of ROS/RNS promotes cancer migration (Nishikawa 2008), while overproduction possesses an opposite effect, i.e. significantly reduces cancer cell migration (Fini et al. 2008). Considering the cell viability MTT assay, one could observe that HCT-116 cells are more sensitive than MDA-MB-231 cells, which is in agreement with our earlier findings (Kosaric et al. 2014; Petrovic et al. 2014, 2015). But, redox status parameters measured and presented in this paper suggest that MDA-MB-231 cells are more susceptible to ROS/RNS increasing in treatment with investigated substances. We observed moderate ROS/RNS increasing in HCT-116 cells, and thus increasing in cell migration. In MDA-MB-231 cells lower concentration $(10 \mu \mathrm{M})$ predominantly increased ROS/RNS in less significant extent when it is compared to higher concentration $(100 \mu \mathrm{M})$. According to Nishikawa (2008) and Fini et al. (2008) we consider that moderate increasing of ROS/RNS induced with $10 \mu \mathrm{M}$ of substances promotes cell migration, while higher $100 \mu \mathrm{M}$ treatment induced great oxidative stress and thus decreasing in cell migration potential.

Evidence that these substances possess cytotoxic and antimigratory character (especially on metastatic MDA-MB-231 cells) appears to be promising in terms of considering the further serious examination in vitro and/or in vivo. The exact mechanism of this action still remains unclear and many studies is needed to be done to reveal influence of superoxide anion radical and other radical species on migration processes in origin-different cancer cells.

Acknowledgments. This work was supported by the Ministry of Science and Technological Development of the Republic of Serbia (project III41010 and OI172016).

\section{References}

Almeida C. A., Barry S. A. (2010): Cancer: Basic Science and Clinical Aspects. John Wiley \& Sons, Hoboken, New Jersey

Ananda Kumar C. S., Kavitha C. V., Vinaya K., Benaka Prasad S. B., Thimmegowda N. R., Chandrappa S., Raghavan S. C., Rangappa K. S. (2009): Synthesis and in vitro cytotoxic evaluation of novel diazaspiro bicyclo hydantoin derivatives in human leukemia cells: a SAR study. Invest. New Drugs 27, 327-337 https://doi.org/10.1007/s10637-008-9179-3

Angelis C., Milano M., Stanzione B., Gargiulo P., Placido S., Arpino G. (2013): Combination of cytotoxic drugs for patients with HER2-negative metastatic breast cancer. Comb. Prod. Therapy 3, 25-37 https://doi.org/10.1007/s13556-013-0004-8

Auclair C., Voisin E. (1985): Nitroblue tetrazolium reduction. In: Handbook of Methods for Oxygen Radical Research. (Ed. R. A. Greenwald), CRC Press, Boca Raton

Baker M. A., Cerniglia G. J., Zaman A. (1990): Microtiter plate assay for the measurement of glutathione and glutathione disulfide 
in large numbers of biological samples. Anal. Biochem. 190, 360-365 https://doi.org/10.1016/0003-2697(90)90208-Q

Basappa, Ananda Kumar C. S., Nanjunda Swamy S., Sugahara K., Rangappa K. S. (2009): Anti-tumor and anti-angiogenic activity of novel hydantoin derivatives: Inhibition of VEGF secretion in liver metastatic osteosarcoma cells. Bioorg. Med. Chem. 17, 4928-4934

Blagosklonny M. V., Fojo T. (1999): Mecular effects of paclitaxel: myths and reality (a critical review). Int. J. Cancer 83, 151-156 https://doi.org/10.1002/(SICI)1097-0215(19991008)83:2<151::AID-IJC1>3.0.CO;2-5

Brodin O., Eksborg S., Wallenberg M., Asker-Hagelberg C., Larsen E. H., Mohlkert D., Lenneby-Helleday C., Jacobsson H., Linder S., Misra S., Björnstedt M. (2015): Pharmacokinetics and toxicity of sodium selenite in the treatment of patients with carcinoma in a phase I clinical trial: The SECAR Study. Nutrients 7, 4978-4994 https://doi.org/10.3390/nu7064978

Bugarčić Ž. D., Bogojeski J., van Eldik R. (2015): Kinetics, mechanism and equilibrium studies on the substitution reactions of $\mathrm{Pd}(\mathrm{II})$ in reference to $\mathrm{Pt}(\mathrm{II})$ complexes with bio-molecules. Coord. Chem. Rev. 292, 91-106 https://doi.org/10.1016/j.ccr.2015.02.016

Bugarcic Z. M., Divac V. M., Kostic M. D., Jankovic N. Z., Heinemann F. W., Radulovic N. S., Stojanovic-Radic Z. Z. (2015): Synthesis, crystal and solution structures and antimicrobial screening of palladium(II) complexes with 2-(phenylselanylmethyl)oxolane and 2-(phenylselanylmethyl)oxane as ligands. J. Inorg. Biochem. 143, 9-19 https://doi.org/10.1016/j.jinorgbio.2014.11.002

Chen Y-C., Prabhu K. S., Mastro A. M. (2013): Is selenium a potential treatment for cancer metastasis? Nutrients 5, 1149-1168 https://doi.org/10.3390/nu5041149

Cordero M., deMiguel M. (2012): Oxidative therapy against cancer. In: Oxidative Stress and Diseases. (Eds. V. I. Lushchak and D. V. Gospodaryov), pp. 497-520. InTech https://doi.org/10.5772/33251

Deb J., Majumder J., Bhattacharyya S., Jana S. S. (2014): A novel naproxen derivative capable of displaying anti-cancer and antimigratory properties against human breast cancer cells. BMC Cancer 14, 1471-2407 https://doi.org/10.1186/1471-2407-14-567

Disalvar A., Saboury A. A., Ahadi L., Zemanatiyar E., MansouriTorshizi H., Ajloo D., Sarma R. H. (2011): biological evaluation and interaction of a newly designed anti-cancer Pd(II) complex and human serum albumin. J. BioMol. Struct. Dyn. 29, 283-296 https://doi.org/10.1080/07391102.2011.10507385

Eckhardt B. L., Francis P. A., Parker B. S., Anderson R. L. (2012): Strategies for the discovery and development of therapies for metastatic breast cancer. Nat. Rev. Drug Discov. 11, 479-497 https://doi.org/10.1038/nrd2372

Entschladen F., Drell T. L. 4th, Lang K., Masur K., Palm D., Bastian P., Niggemann B., Zaenker K. S. (2005): Analysis methods of human cell migration. Exp. Cell. Res. 307, 418-426 https://doi.org/10.1016/j.yexcr.2005.03.029

Ferrer-Sueta G., Radi R. (2009): Chemical biology of peroxynitrite: kinetics, diffusion, and radicals. ACS Chem. Biol. 4, 161-177 https://doi.org/10.1021/cb800279q

Fini M. A., Orchard-Webb D., Kosmider B., Amon J. D., Kelland R., Shibao G., Wright R. M. (2008): Migratory activity of human breast cancer cells is modulated by differential expression of xanthine oxidoreductase. J. Cell. Biochem. 105, 1008-1026 https://doi.org/10.1002/jcb.21901

Griess P. (1879): Bemerkungen zu der Abhandlung der HH. Weselsky und Benedikt Ueber einige Azoverbindungen". Ber. Dtsch. Chem. Ges. 12, 426-428 https://doi.org/10.1002/cber.187901201117

Halliwell B., Gutteridge J. (2007): Free Radicals in Biology and Medicine. Oxford University Press: New York

Hancock J. T., Desikan R., Neill S. J. (2001): Role of reactive oxygen species in cell signalling pathways. Biochem. Soc. Trans. 29, 345-350 https://doi.org/10.1042/bst0290345

Hmuda S., Trišović N., Rogan J., Poleti D., Vitnik Ž., Vitnik V., Valentić N., Božić B., Ušćumlić G. (2014): New derivatives of hydantoin as potential antiproliferative agents: biological and structural characterization in combination with quantum chemical calculations. Monatsh. Chem. 145, 821-833 https://doi.org/10.1007/s00706-013-1149-6

Javois L. C. (1999): Immunocytochemical Methods and Protocols. (Eds. C. Oliver and M. C. Jamur), Vol 115, Humana Press, New York https://doi.org/10.1385/1592592139

Jevtic V. V., Radic G. P., Seklic D., Zivanovic D. M., Markovic S., Trifunovic S. R. (2014): Part XVI - Stereospecific ligands and their complexes. Synthesis, characterization and in vitro antiproliferative activity of new platinum(IV) complexes with some O,O'-dialkyl esters of (S,S)-ethylenediamine-N,N'-di2-propanoic acid against breast cancer. MJCCE 33, 53-58 https://doi.org/10.20450/mjcce.2014.148

Kalinowska-Lis U., Ochocki J., Matlawska-Wasowska K. (2008): Trans geometry in platinum antitumor complexes. Coord. Chem. Rev. 252, 1328-1345 https://doi.org/10.1016/j.ccr.2007.07.015

Kosaric J. V., Cvetkovic D. M., Zivanovic M. N., Curcic M. G., Seklic D. S., Bugarcic Z. M., Markovic S. D. (2014): Antioxidative and antiproliferative evaluation of 2-(phenylselenomethyl) tetrahydrofuran and 2-(phenylselenomethyl)tetrahydropyran. J. Buon 19, 283-290

Kushev D., Gorneva G., Enchev V., Naydenova E., Popova J., Taxirov S., Maneva L., Grancharov K., Spassovska N. (2002): Synthesis, cytotoxicity, antibacterial and antitumor activity of platinum(II) complexes of 3-aminocyclohexanespiro-5-hydantoin. J. Inorg. Biochem. 89, 203-211 https://doi.org/10.1016/S0162-0134(01)00420-2

Lancaster J. R., Jr. (2006): Nitroxidative, nitrosative, and nitrative stress: kinetic predictions of reactive nitrogen species chemistry under biological conditions. Chem. Res. Toxicol. 19, 1160-1174 https://doi.org/10.1021/tx060061w

Liu Q., Gross S. S. (1996): Binding sites of nitric oxide synthases. Methods Enzym. 268, 311-324

https://doi.org/10.1016/S0076-6879(96)68033-1

Liu Y., Li W., Guo M., Li C., Qiu C. (2015): Protective role of selenium compounds on the proliferation, apoptosis, and an- 
giogenesis of a canine breast cancer cell line. Biol. Trace Elem. Res. 169, 86-93 https://doi.org/10.1007/s12011-015-0387-3

Markovic S. D., Djacic D. S., Cvetkovic D. M., Obradovic A. D., Zizic J. B., Ognjanovic B. I., Stajn A. S. (2011): Effects of acute in vivo cisplatin and selenium treatment on hematological and oxidative stress parameters in red blood cells of rats. Biol. Trace Elem. Res. 142, 660-670 https://doi.org/10.1007/s12011-010-8788-9

Matovic Z. D., Mrkalic E., Bogdanovic G., Kojic V., Meetsma A., Jelic R. (2013): Antitumor effects of a tetradentate amido-carboxylate ligands and corresponding square-planar palladium(II) complexes toward some cancer cells. Crystal structure, DFT modeling and ligand to DNA probe docking simulation. J. Inorg. Biochem. 121, 134-144 https://doi.org/10.1016/j.jinorgbio.2013.01.006

Mosmann T. (1983): Rapid colorimetric assay for cellular growth and survival: application to proliferation and cytotoxicity assays. J. Immunol. Methods 65, 55-63 https://doi.org/10.1016/0022-1759(83)90303-4

Mudit M., Khanfar M., Muralidharan A., Thomas S., Shah G. V., van Soest R. W., El Sayed K. A. (2009): Discovery, design, and synthesis of anti-metastatic lead phenylmethylene hydantoins inspired by marine natural products. Bioorg. Med. Chem. 17, 1731-1738 https://doi.org/10.1016/j.bmc.2008.12.053

Mut-Salud N., Álvarez P. J., Garrido J. M., Carrasco E., Aránega A., Rodríguez-Serrano F. (2016): Antioxidant intake and antitumor therapy: Toward nutritional recommendations for optimal results. Oxid. Med. Cell. Longev. 6719534 https://doi.org/10.1155/2016/6719534

Petrovic V. P., Simijonovic D., Zivanovic M. N., Kosaric J. V., Petrovic Z. D., Markovic S., Markovic S. D. (2014): Vanillic Mannich bases: synthesis and screening of biological activity. Mechanistic insight into the reaction with 4-chloroaniline. RSC Advances 4, 24635-24644 https://doi.org/10.1039/C4RA03909B

Nishikawa M. (2008): Reactive oxygen species in tumor metastasis. Cancer Lett. 266, 53-59 https://doi.org/10.1016/j.canlet.2008.02.031

Petrovic V. P., Zivanovic M. N., Simijonovic D., Dorovic J., Petrovic Z. D., Markovic S. D. (2015): Chelate N,O-palladium(ii) complexes: synthesis, characterization and biological activity. RSC Advances 5, 86274-86281

https://doi.org/10.1039/C5RA10204A

Polyak K., Weinberg R. A. (2009): Transitions between epithelial and mesenchymal states: acquisition of malignant and stem cell traits. Nat. Rev. Cancer 9, 265-273 https://doi.org/10.1038/nrc2620

Pompella A., Visvikis A., Paolicchi A., De Tata V., Casini A. F. (2003): The changing faces of glutathione, a cellular protagonist. Biochem. Pharmacol. 66, 1499-1503
https://doi.org/10.1016/S0006-2952(03)00504-5

Sabo T. J., Kaluđerović G. N., Grgurić-Šipka S. R., Heinemann F. W., Trifunović S. R. (2004): Complex compounds of platinum(IV) and O,O-dialkyl-ethylenediamine- $\mathrm{N}, \mathrm{N}^{\prime}$-di3-propanoate ligands. A structural evidence for geometry of hydrolytic product of some esters. Inorg. Chem. Comm. 7, 241-244 https://doi.org/10.1016/j.inoche.2003.11.007

Schroeder C. P., Goeldner E. M., Schulze-Forster K., Eickhoff C. A., Holtermann P., Heidecke H. (2004): Effect of selenite combined with chemotherapeutic agents on the proliferation of human carcinoma cell lines. Biol. Trace Elem. Res. 99, $17-25$

https://doi.org/10.1385/BTER:99:1-3:017

Šmit B. M., Pavlović R. Z. (2015): Three-step synthetic pathway to fused bicyclic hydantoins involving a selenocyclization step. Tetrahedron 71, 1101-1108 https://doi.org/10.1016/j.tet.2014.12.088

Ulukaya E., Ari F., Dimas K., Ikitimur E. I., Guney E., Yilmaz V. T. (2011): Anti-cancer activity of a novel palladium(II) complex on human breast cancer cells in vitro and in vivo. Eur. J. Med. Chem. 46, 4957-4963 https://doi.org/10.1016/j.ejmech.2011.07.055

Urbich C., Dernbach E., Aicher A., Zeiher A. M., Dimmeler S. (2002): CD40 ligand inhibits endothelial cell migration by increasing production of endothelial reactive oxygen species. Circulation 106, 981-986 https://doi.org/10.1161/01.CIR.0000027107.54614.1A

Varbanov H., Bakalova A., Buyukliev R., Momekov G., Baykushev R. (2010): Synthesis of palladium(II) complexes with 3-amino5-methyl-5-(4-pyridyl)-hydantoin: cytotoxic and antimicrobial investigations and comparison with their platinum analogues. Trans. Met. Chem. 35, 457-461 https://doi.org/10.1007/s11243-010-9349-y

Wu Z., Li X., Sunkara M., Spearman H., Morris A. J., Huang C. (2011): PIPKIgamma regulates focal adhesion dynamics and colon cancer cell invasion. PLoS One 6, 12

Xu W., Liu L. Z., Loizidou M., Ahmed M., Charles I. G. (2002): The role of nitric oxide in cancer. Cell. Res. 12, 311-320 https://doi.org/10.1038/sj.cr.7290133

Zec M., Srdic-Rajic T., Konic-Ristic A., Todorovic T., Andjelkovic K., Filipovic-Ljeskovic I., Radulovic S. (2012): Anti-metastatic and anti-angiogenic properties of potential new anti-cancer drugs based on metal complexes of selenosemicarbazones. Anticancer Agents Med. Chem. 12, 1071-1080 https://doi.org/10.2174/187152012803529682

Received: June 14, 2016

Final version accepted: August 16, 2016

First published online: February 2, 2017 